PEMBELAJAR: Jurnal Ilmu Pendidikan, Keguruan, dan Pembelajaran

Volume 3 Nomor 1 April 2019

e-ISSN: 2549-9114 dan p-ISSN: 2549-9203

(Received: Januari 2019 ; Reviewed: Februari-2019; Published: April 2019)

DOI: https://doi.org/10.26858/pembelajar.v3i1.5778

\title{
Pembelajaran Program Khusus Orientasi Mobilitas Bagi Peserta Didik Tunanetra Di Sekolah Luar Biasa
}

\author{
Anita Yudhiastuti ${ }^{\mathrm{a}}$, Nur Azizah ${ }^{\mathrm{b}}$ \\ ${ }^{\text {a }}$ Program Pascasarjana Pendidikan Luar Biasa, UNY \\ Corresponding email: anitayudhias@yahoo.com
}

\begin{abstract}
Abstrak: Penelitian ini bertujuan untuk mendeskripsikan pembelajaran program khusus orientasi mobilitas bagi peserta didik tunanetra di SLB PGRI Sentolo. Penelitian ini merupakan penelitian deskriptif dengan pendekatan kualitatif. Subjek penelitian yaitu satu guru orientasi mobilitas dan peserta didik tunanetra. Teknik pengumpulan data dilakukan dengan wawancara, observasi dan dokumentasi. Analisis data dilakukan dengan reduction, data display, and conclusion drawing/ verification. Hasil penelitian menunjukan bahwa tahap persiapan dilakukan dengan melakukan asesmen, menyusun silabus dan menyusun RPP. Pelaksanaan dilakukan meliputi tiga kegiatan yaitu kegiatan pendahuluan, kegiatan inti dan kegiatan penutup. Kegiatan pendahuluan berisi kegiatan memotivasi, memusatkan perhatian dan mengetahui kemampuan yang telah dikuasai. Pada kegiatan inti, guru sering menggunakan metode ceramah dan praktik. Guru menggunakan media benda sekitar. Pada proses pembelajaran bahan ajar belum digunakan secara optimal. Pada kegiatan penutup dilakukan penilaian. Pada tahap evaluasi, guru melakukan evaluasi formatif pada proses pembelajaran dan setelah pembelajaran. Evaluasi dilakukan dengan observasi dan tes praktik. Rekomendasi penelitian selanjutnya yaitu dapat melakukan upaya intervensi untuk meningkatkan kualitas pembelajaran seperti melakukan inovasi pada media, bahan ajar, dan penilaian.
\end{abstract}

Kata kunci: pembelajaran program khusus orientasi mobilitas, peserta didik tunanetra

\begin{abstract}
This study aims to describe the learning of a special program of mobility orientation for students with visual impairment in SLB PGRI Sentolo. This research is a descriptive research with qualitative approach. The subject of research is one teacher of orientation mobility and student with visual impairment. Technique of collecting data is done by interview, observation and documentation. Data analysis is done by reduction, display data, and conclusion drawing / verification. The results showed that the preparation was done by conducting the assessment, preparing the syllabus and preparing the RPP. The implementation consists of three activities: preliminary activities, core activities and closing activities. Preliminary activities contain activities that motivate, focus attention, and know the capabilities that have been mastered. In the core activities, teachers often use lecture and practice methods. Teachers use the media objects around. In the learning process of learning materials have not been used optimally. At closing activities conducted evaluation. In the evaluation phase, teachers conduct formative evaluation on learning process and after learning. Evaluation is done by observation and practice test. The next research recommendation is to make intervention efforts to improve the quality of learning such as innovation on media, teaching materials, and evaluation.
\end{abstract}

Key words: learning of special program of orientation mobility, visual impairment students 


\section{PENDAHULUAN}

Tunanetra merupakan istilah yang digunakan untuk menjelaskan kondisi hilangnya penglihatan baik sebagian maupun seluruhnya. Peserta didik dengan gangguan penglihatan kesulitan atau bahkan tidak mampu menerima rangsang visual sehingga indera penglihatan tidak menjadi saluran utama yang digunakan untuk belajar. Peserta didik tunanetra menggunakan sentuhan dan pendengaran untuk belajar (Friend \& Bursick, 2012:185). Kondisi ini menyebabkan peserta didik tunanetra membutuhkan alat bantu khusus, metode khusus, atau teknik-teknik tertentu untuk dapat belajar.

Kondisi tunanetra menyebabkan peserta didik memiliki beberapa keterbatasan. Ada tiga keterbatasan yang dialami tunanetra yaitu keterbatasan dalam lingkup keberagaman pengalaman, keterbatasan berinteraksi dengan lingkungan dan keterbatasan berpindah tempat (Turnbull, Turnbull, Wehmeyer \& Shogren, 2013: 366). Keterbatasan berpindah tempat merupakan keterbatasan utama yang dialami oleh seorang tunanetra. Kemampuan berpindah tempat dapat mengurangi keterbatasanketerbatasan dalam berkomunikasi, berinteraksi dengan lingkungan dan berbagai bidang kehidupan lainnya (Hidayat \& Suwandi, 2013: 46). Jika seorang tunanetra dapat bergerak atau berpindah tempat secara bebas maka seseorang dapat berinteraksi dengan lingkungan dan memperoleh banyak pengalaman sehingga dapat berdampak positif bagi berbagai aspek perkembangan peserta didik. Hal inilah yang menjadi alasan pentingnya mengatasi keterbatasan dalam berpindah tempat. Keterbatasan pada peserta didik tunanetra dalam bergerak atau berpindah tempat dapat diatasi melalui program orientasi dan mobilitas.

Orientasi dan mobilitas terdiri dari dua aktivitas yang tidak dapat dipisahkan. Orientasi merupakan penggunaan indera yang masih berfungsi untuk mengetahui tanda, isyarat, benda dan orang di lingkungan yang akan menjadi peta mental tentang lingkungan, sedangkan mobilitas kemampuan berpindah tempat menuju ke tempat lain secara aman dan efisien (Smith \& Tyler, 2010: 378; Friend \& Bursick, 2012:185). Ketika akan melakukan mobilitas, seseorang terlebih dahulu melakukan orientasi mengenai benda dan tanda penting di sekitarnya, seperti posisi meja, kursi, lemari dan sebagainya. Kegiatan ini akan memberikan gambaran kepada seorang tunanetra tentang kondisi lingkungan di sekitarnya. Seseorang akan melakukan mobilitas sesuai dengan gambaran lingkungan yang telah di orientasi. Keterampilan orientasi dan mobilitas dapat membantu seseorang untuk bergerak di lingkungannya saat ini dan sangat mendukung kemandirian di lingkungan nantinya (Gargiulo \& Kilgo, 2005: 293). Hal inilah yang menjadikan program orientasi dan mobilitas menjadi penting untuk diberikan pada peserta didik tunanetra.

Program orientasi dan mobilitas diberikan pada peserta didik tunanetra sebagai program kekhususan. Pada Kurikulum Tingkat Satuan Pendidikan, program orientasi mobilitas merupakan program yang berdiri sendiri dan hanya memuat pembelajaran orientasi mobilitas, sedangkan kurikulum 2013, program orientasi mobilitas terintegrasi dengan dua program khusus lainnya yaitu sosial dan komunikasi, sehingga program ini diberi nama program khusus orientasi mobilitas, sosial dan komunikasi (OMSK). Pada dasarnya, pada KTSP ataupun Kurikulum 2013 berupaya memberikan program khusus sebagai bentuk kompensasi dari hambatan pengelihatan yang dialami peserta didik tunanetra dengan tujuan untuk meminimalisir hambatan dan meningkatkan akses dalam pembelajaran.

Pada kurikulum 2013, program khusus dikembangkan tidak berdasarkan jenjang, satuan pendidikan dan tingkat kelas (Kemendikbud, 2014: 37). Pada program orientasi mobilitas 
penguasaan kemampuan dan indikator tidak harus berurutan karena disesuaikan dengan kebutuhan peserta didik tunanetra. Artinya pelaksanaan program orientasi mobilitas bersifat fleksibel. Pelaksanaan program orientasi mobilitas diawali dengan asesmen peserta didik tunanetra. Hasil asesmen ini menjadi dasar dalam pengembangan program orientasi mobilitas pada peserta didik tunanetra.

Program orientasi mobilitas ini diberikan pada peserta didik tunanetra, salah satunya di SLB PGRI Sentolo. Pembelajaran program khusus orientasi mobilitas dilakukan agar peserta didik memiliki kemampuan dan keinginan untuk bergerak dan berpindah tempat. Program orientasi mobilitas diberikan dari yang sederhana ke kompleks serta mempertimbangkan kemampuan peserta didik tunanetra. Berdasarkan hasil observasi kemampuan orientasi dan mobilitas menunjukan bahwa peserta didik tunanetra ketika berjalan masih sering menabrak, belum menggunakan teknik-teknik orientasi dan mobilitas, peserta didik sering digandeng oleh temannya. Hal ini berarti peserta didik tunanetra belum mampu bergerak secara mandiri dan masih tergantung pada orang lain. Kondisi ini dapat terjadi karena beberapa faktor salah satunya proses pembelajaran. Magalhaes, Sankako \& Braccialli (2014: 1) mengemukakan bahwa beberapa strategi yang digunakan guru sering menghambat orientasi dan mobilitas pada peserta didik. Adanya fenomena ini memerlukan kajian lebih lanjut mengenai pembelajaran orientasi dan mobilitas di SLB PGRI Sentolo. Selain itu, belum banyak informasi yang mengungkapkan secara lengkap mengenai pembelajaran program khusus orientasi mobilitas, sehingga penelitian ini penting untuk dilakukan. Oleh karena itu, penelitian ini difokuskan untuk menghasilkan gambaran mengenai pembelajaran program khusus orientasi mobilitas pada peserta didik tunanetra di SLB PGRI Sentolo.

Proses pembelajaran terdiri dari tahap persiapan, pelaksanaan dan evaluasi. Proses pembelajaran didukung oleh beberapa komponen. Komponen dalam kegiatan pembelajaran peserta didik tunanetra terdiri dari tujuan pembelajaran, bahan pelajaran, metode pembelajaran, alat pembelajaran, sumber belajar, media pembelajaran serta evaluasi pembelajaran (Rudiyati, 2002: 45). Komponen pembelajaran ini akan saling mendukung dalam menentukan keberhasilan pembelajaran. Penelitian ini mendeksripsikan pembelajaran program khusus orientasi mobilitas pada peserta didik tunanetra di SLB PGRI Sentolo. Penelitian ini berfokus pada persiapan, proses dan evaluasi pembelajaran program khusus orientasi mobilitas pada peserta didik tunanetra di SLB PGRI Sentolo.

\section{METODE}

Penelitian ini menggunakan pendekatan kualitatif. Penelitian ini dilaksanakan di SLB PGRI Sentolo. Hal ini dikarenakan sekolah ini memberikan layanan pendidikan bagi peserta didik tunanetra. Penelitian ini memperoleh deskripsi mengenai pembelajaran program khusus orientasi mobilitas pada peserta didik tunanetra di SLB PGRI Sentolo yang meliputi tahap persiapan, proses dan evaluasi pembelajaran. Penelitian dilaksanakan selama empat minggu pada bulan November. Pembelajaran program khusus orientasi dan mobilitas dilaksanakan setiap hari sabtu pukul 09.00-10.10 sehingga pengambilan data dilakukan setiap hari dan jam tersebut.

Penelitian ini melibatkan satu guru orientasi mobilitas dan peserta didik tunanetra. Guru yang mengajar orientasi mobilitas ini berjenis kelamin perempuan dan berusia 57 tahun. Guru merupakan lulusan strata 1 pendidikan luar biasa dan mengambil konsentrasi tunanetra. Guru ini berstatus pegawai negeri sipil dan telah mengajar di Sekolah Luar Biasa (SLB) selama 21 tahun sejak November 1996. Partisipan dipilih karena guru tersebut mengajar orientasi mobilitas pada siswa tunanetra. Penelitian ini menggali data mengenai pembelajaran orientasi 
mobilitas meliputi tahap persiapan, pelaksanaan dan evaluasi dengan meninjau tujuan pembelajaran, bahan pelajaran, metode pembelajaran, alat belajar, sumber belajar, media pembelajaran dan evaluasi belajar pada setiap tahapnya.

Teknik pengumpulan data yang digunakan yaitu observasi, wawancara dan dokumentasi. Penelitian ini menggunakan pedoman observasi dalam melakukan pengamatan. Observasi dilakukan dengan mengamati guru dan siswa dari tahap persiapan, pelaksanaan dan evaluasi pada pembelajaran program khusus orientasi dan mobilitas. Wawancara dilakukan kepada guru orientasi dan mobilitas mengenai persiapan, pelaksanaan dan evaluasi dalam pembelajaran program khusus orientasi dan mobilitas. Wawancara dilaksanakan dengan mengajukan pertanyaan-pertanyaan berdasarkan pedoman wawancara. Dokumentasi dilakukan dengan meninjau dokumen seperti RPP.

Data dianalisis secara deskriptif kualitatif. Analisis data dilakukan dengan langkah analisis data menurut Miles dan Huberman yang terdiri dari reduction, data display, and conclusion drawing / verification (Sugiyono, 2012: 337). Reduksi data dilakukan dengan memilah data dari wawancara, observasi dan dokumentasi dengan disesuaikan dengan pertanyaan penelitian. Penyajian data dilakukan dalam bentuk narasi. Penarikan kesimpulan dilakukan dengan mengklasifikasikan data yang dianalisis sesuai dengan pertanyaan penelitian serta pemberian pemaknaan.

\section{HASIL DAN PEMBAHASAN}

\subsection{Hasil}

Pembelajaran orientasi mobilitas merupakan program khusus yang diberikan pada peserta didik tunanetra sebagai kompensatoris dari gangguan pengelihatan yang dialaminya. Di SLB PGRI Sentolo pembelajaran orientasi mobilitas dilaksanakan satu minggu sekali yaitu setiap sabtu pukul 09.00-10.10. Pembelajaran ini diberikan dari yang sederhana ke kompleks serta mempertimbangkan kemampuan peserta didik tunanetra, sehingga pelaksanaan program ini dilaksanakan secara individual. Pembelajaran orientasi mobilitas di SLB PGRI Sentolo dimulai dari tahap persiapan atau perencanaan, tahap pelaksanaan dan tahap evaluasi. Berikut rincian pelaksanaan setiap tahap tersebut, yaitu:

a. Tahap persiapan atau perencanaan

Pembelajaran orientasi mobilitas yang dilaksanakan di SLB PGRI Sentolo diawali dengan melakukan persiapan atau perencanaan pembelajaran. Persiapan diawali dengan melakukan asesmen kemampuan orientasi mobilitas peserta didik tunanetra. Asesmen dilakukan dengan observasi saat peserta didik berada di sekolah dan wawancara dengan orang tua mengenai aktivitas yang biasa dilakukan peserta didik ketika di rumah. Hasil asesmen akan memperoleh gambaran mengenai kemampuan dan kebutuhan orientasi mobilitas peserta didik. Hasil asesmen ini menjadi dasar bagi guru untuk menetapkan tujuan pembelajaran. Tahap perencanaan pembelajaran dilakukan dengan menyusun silabus dan menyusun RPP.

Silabus pembelajaran orientasi mobilitas disusun oleh guru orientasi mobilitas. Silabus ini disusun pada awal tahun ajaran baru. Silabus disusun sesuai dengan kurikulum yang berlaku yaitu kurikulum 2013 dan mengacu pada kompetensi inti serta kompetensi dasar. Komponen silabus terdiri dari nama sekolah, mata pelajaran semester, kompetensi dasar, materi pembelajaran, kegiatan pembelajaran, indikator pencapaian, penilaian, alokasi waktu dan sumber belajar.

RPP orientasi mobilitas disusun oleh guru sebagai upaya untuk mempersiapkan pelaksanaan pembelajaran. Satu RPP dapat mencakup materi pembelajaran untuk beberapa kali pertemuan. Komponen yang terdapat pada RPP terdiri dari nama sekolah, kelas atau semester, mata 
pelajaran, alokasi waktu, kompetensi inti, kompetensi dasar, tujuan pembelajaran, materi pembelajaran, metode pembelajaran, langkah pembelajaran, sumber belajar dan penilaian.

Materi pembelajaran mencakup teknik pra tongkat yaitu bepergian dengan teknik melindungi diri di lingkungan yang terdiri dari menggunakan teknik menyilang tangan di atas (upper hand), menggunakan teknik menyilang tangan ke bawah (lower hand), menggunakan teknik merambat (trailing), menggunakan teknik tegak lurus dengan benda (squaring off) dan menggunakan teknik mencari benda jatuh. Media pembelajaran yang dipersiapkan berupa benda seperti pensil, buku, meja, dan benda di sekitar. Metode pembelajaran yang akan dilakukan yaitu ceramah dan praktik. Penilaian direncanakan dengan jenis tes praktik.

b. Tahap pelaksanaan

Pembelajaran orientasi mobilitas diikuti oleh satu peserta didik tunanetra. Peserta didik ini duduk di kelas IV SD. Pelaksanaan kegiatan pembelajaran terdiri dari kegiatan pendahuluan, kegiatan inti dan kegiatan penutup. Pada kegiatan pendahuluan ditunjukan dengan guru membuka pembelajaran dengan mengucapkan salam, dilanjutkan dengan berdoa dan menyapa peserta didik. Guru mengkondisikan peserta didik untuk fokus mengikuti pembelajaran, selanjutnya guru menyampaikan tujuan pembelajaran yang akan dicapai.

Kegiatan inti dimulai dengan guru menyampaikan materi. Saat penyampaian materi guru melakukan metode ceramah dan menyentuh atau memberikan contoh penggunaan teknik yang benar. Metode praktik dilakukan untuk melatih peserta didik melakukan teknik seperti yang telah dicontohkan oleh guru. Media pembelajaran yang digunakan yaitu benda yang ada di sekitar seperti pensil, stilus, meja, kursi. Bahan ajar belum digunakan secara optimal sehingga pembelajaran terpusat pada guru. Kegiatan penutup dilakukan dengan penilaian. Penilaian dilakukan dengan tes praktik kemampuan peserta didik dalam melaksanakan teknikteknik yang telah diajarkan.

c. Tahap Evaluasi

Tahap evaluasi dilaksanakan ketika proses pembelajaran dan di akhir pembelajaran. Aspek yang dievaluasi mencakup kemampuan peserta didik dalam mempraktikan teknik dan sikap dalam proses pembelajaran. Kemampuan peserta didik dievaluasi dengan melakukan tes praktik. Guru juga melakukan evaluasi dengan membandingkan perbedaan kemampuan peserta didik sebelum belajar dan setelah belajar. Selain itu, guru juga melakukan observasi tentang sikap peserta didik saat mengikuti pembelajaran.

\subsection{Pembahasan}

Proses pembelajaran di SLB PGRI Sentolo diawali dengan persiapan, pelaksanaan dan evaluasi pembelajaran. Hal ini sejalan dengan pendapat Ambarita (2006: 66) bahwa proses pembelajaran dimulai dengan tahap perencanaan, pelaksanaan dan evaluasi. Program orientasi mobilitas bersifat individual, sehingga harus disesuaikan dengan kebutuhan siswa. Pada tahap persiapan guru terlebih dahulu melakukan asesmen tentang kemampuan dan kebutuhan orientasi mobilitas pada siswa. Hal ini sejalan dengan pendapat Mumpuniarti (2003: 70) rancangan program yang dikembangkan dengan pendekatan individual dilakukan melalui asesmen. Hasil asesmen ini menjadi dasar bagi guru menyusun program. Hasil asesmen ini juga dapat digunakan oleh guru atau ahli lain sebagai rujukan dari kondisi siswa.

Guru merancang silabus sesuai dengan kurikulum yang berlaku yaitu kurikulum 2013. 
Guru sudah menyusun RPP pembelajaran orientasi mobilitas secara garis besar yang terdiri dari nama sekolah, kelas atau semester, mata pelajaran, alokasi waktu, kompetensi inti, kompetensi dasar, tujuan pembelajaran, materi pembelajaran, metode pembelajaran, langkah pembelajaran, sumber belajar dan penilaian. RPP ini dikembangkan dengan mengacu pada silabus yang telah disusun. RPP yang disusun guru telah sesuai dengan cakupan RPP berdasarkan Permendikbud no 81 A tahun 2013 tentang implementasi kurikulum pedoman umum pembelajaran yang menjelaskan tahap pertama dalam pemebejaran menurut standar proses yaitu merancang RPP dengan mengacu pada silabus, RPP mencakup data sekolah, mata pelajaran, kelas atau semester, materi, metode, media, langkah pembelajaran dan penilaian. Materi pembelajaran mencakup teknik pra tongkat. Media pembelajaran yang dipersiapkan berupa benda seperti pensil, buku, meja, dan benda di sekitar. Metode pembelajaran yang akan dilakukan yaitu ceramah dan praktik. Penilaian direncanakan dengan jenis tes praktik.

Pada tahap pelaksanaan pembelajaran orientasi mobilitas meliputi kegiatan pendahuluan, kegiatan inti dan kegiatan penutup. Kegiatan pendahuluan dilakukan dengan guru membuka pembelajaran dengan mengucapkan salam, dilanjutkan dengan berdoa dan menyapa peserta didik. Guru secara konsisten mengkondisikan peserta didik untuk fokus mengikuti pembelajaran, selanjutnya guru menyampaikan tujuan pembelajaran yang akan dicapai. Hal ini relevan dengan pendapat Majid (2012: 104) menjelaskan bahwa kegiatan pendahuluan dilakukan untuk memotivasi, memusatkan perhatian dan mengetahui apa yang telah dikuasai anak mengenai materi yang dipelajari.

Kegiatan inti dimulai dengan guru menyampaikan materi. Saat penyampaian materi guru melakukan metode ceramah dan menyentuh atau memberikan contoh penggunaan teknik yang benar. Metode praktik dilakukan untuk melatih peserta didik melakukan teknik seperti yang telah dicontohkan oleh guru. Metode yang digunakan guru telah tercakup dalam beberapa metode yang dikemukakan oleh Widjaya (2013: 63) bahwa ada beberapa metode pembelajaran yaitu metode ceramah, demonstrasi, simulasi, latihan, tanya jawab, dan penugasan. Guru hanya menggunakan kedua metode tersebut dalam pembelajaran, sehingga kurang bervariasi. Guru dapat menggunakan model pembelajaran langsung dalam proses pembelajaran orientasi mobilitas. Ratnasari \& Pamuji (2015:1) menemukan bahwa model pembelajaran langsung di lingkungan sekolah dapat meningkatkan kemampuan orientasi mobilitas peserta didik tunanetra. Media pembelajaran yang digunakan yaitu benda yang ada di sekitar seperti pensil, stilus, meja, kursi. Hal ini sejalan dengan pendapat (Riyana, 2009: 40) tentang pengklasifikasian media yaitu media gambar, media benda asli, orangserta model. Media yang digunakan guru dalam pembelajaran orientasi mobilitas yaitu media benda asli dengan memanfaatkan benda sekitar. Bahan ajar belum digunakan secara optimal sehingga pembelajaran terpusat pada guru. Padahal penggunaan bahan ajar sangat penting dalam proses pembelajaran. Majid (2012: 173) mengemukakan bahwa bahan ajar merupakan berbagai bentuk bahan yang digunakan untuk membantu guru dalam melaksanakan kegiatan pembelajaran. Kegiatan penutup dilakukan penilaian. Penilaian dilakukan dengan tes praktik kemampuan peserta didik dalam melaksanakan teknik-teknik yang telah diajarkan. Hal ini sejalan dengan pendapat Majid (2012: 104) bahwa kegiatan penutup merupakan kegiatan memberikan penugasan atau kesimpulan dan penilaian terhadap penugasan.

Tahap evaluasi dilaksanakan ketika proses pembelajaran dan di akhir pembelajaran. Aspek yang dievaluasi mencakup kemampuan peserta didik dalam mempraktikan teknik dan sikap dalam proses pembelajaran. Kemampuan peserta didik dievaluasi dengan melakukan tes praktik. 
Guru juga melakukan evaluasi dengan membandingkan perbedaan kemampuan peserta didik sebelum belajar dan setelah belajar. Selain itu, guru juga melakukan observasi tentang sikap peserta didik saat mengikuti pembelajaran. Hal ini berarti bahwa guru telah melakukan evaluasi formatif, hal ini sejalan dengan pendapat Sudijono (2007: 23) menjelaskan bahwa evaluasi formatif dilaksanakan di tengah pembelajaran atau pada saat pembelajaran berlangsung, dilaksanakan pada setiap satuan pembelajaran atau subpokok bahasan dapat diselesaikan untuk mengetahui pencapaian tujuan pembelajaran.

Temuan pada penelitian ini menunjukan bahwa pembelajaran orientasi mobilitas di sekolah telah dilaksanakan. Tahapan pembelajaran meliputi tahap perencanaan atau persiapan, tahap pelaksanaan dan tahap evaluasi. Masing-masing tahapan telah terlaksana, namun masih ada beberapa aspek yang membutuhkan perbaikan seperti sebaiknya menggunakan metode pembelajaran yang lebih bervariasi, dan menggunakan bahan ajar untuk menunjang pembelajaran, Hasil penelitian ini menjadi hal yang penting untuk memberikan gambaran mengenai pelaksanaan pembelajaran orientasi mobilitas serta dapat dijadikan sebagai sarana evaluasi pembelajaran orientasi mobilitas. Penelitian selanjutnya dapat melakukan upaya intervensi untuk meningkatkan kualitas pembelajaran pada tahap persiapan, tahap pelaksanaan atau tahap evaluasi. Penelitian selanjutnya dapat melakukan inovasi pada media, bahan ajar, materi, penilaian.

\section{KESIMPULAN DAN SARAN}

\subsection{Kesimpulan}

Berdasarkan hasil kesimpulan dan pembahasan dapat disimpulkan bahwa pembelajaran orientasi mobilitas diawali dengan tahap persiapan atau perencanaan, tahap pelaksanaan dan tahap evaluasi. Persiapan dilakukan dengan melakukan asesmen, menyusun silabus dan menyusun RPP
Pelaksanaan dilakukan meliputi tiga kegiatan yaitu kegiatan pendahuluan, kegiatan inti dan kegiatan penutup. Kegiatan pendahuluan berisi kegiatan memotivasi, memusatkan perhatian dan mengetahui kemampuan yang telah dikuasai. Kegiatan inti, guru sering menggunakan metode ceramah dan praktik. Guru menggunakan media benda sekitar dan bahan ajar yang ada belum digunakan secara optimal. Kegiatan penutup dilakukan dengan melakukan penilaian, Pada tahap evaluasi, guru melakukan evaluasi formatif yang dilakukan pada proses pembelajaran dan setelah pembelajaran. Evaluasi dilakukan dengan observasi dan tes praktik. Rekomendasi untuk penelitian selanjutnya yaitu dapat melakukan upaya intervensi untuk meningkatkan kualitas pembelajaran pada tahap persiapan, tahap pelaksanaan atau tahap evaluasi. Penelitian selanjutnya dapat melakukan inovasi pada media, bahan ajar, materi, penilaian.

\subsection{Saran}

1. Bagi kepala sekolah, kepala sekolah diharapkan membuat kebijakan yang dapat meningkatkan kualitas pembelajaran program khusus orientasi mobilitas bagi peserta didik tunanetra.

2. Bagi guru, guru diharapkan dapat meningkatkan kualitas pembelajaran dengan menggunakan metode pembelajaran yang lebih bervariasi, dan menggunakan bahan ajar secara optimal untuk menunjang pembelajaran.

3. Bagi peneliti, peneliti diharapkan dapat melakukan penelitian lebih mendalam terkait pembelajaran program khusus orientasi mobilitas bagi peserta didik dan melakukan penelitian terkait berbagai inovasi pada metode, media, bahan ajar dan penilaian untuk meningkatkan kualitas pembelajaran program khusus orientasi mobilitas bagi peserta didik tunanetra. 


\section{DAFTAR PUSTAKA}

Ambarita, Alben. (2006). Manajemen Pembelajaran. Jakarta: Depdiknas Direktorat Jendral Pendidikan Tinggi Direktorat Ketenagaan.

Friend, M \& Bursick, W.D. (2012).Including Student with Special Needs: A Practical Guide for Classroom Teacher. Sixth Edition. USA:Pearson

Gargiulo, R. M \& Kilgo, J. L. (2005). Young Children with Special Needs. Second Edition. USA: Delmar Cengage Learning

Hidayat, A.AS. \& Suwandi, A. (2013). Pendidikan Anak Berkebutuhan Khusus Tunanetra. Bandung: Luxima.

Kemendikbud. (2013). Permendikbud No.81 A tentang Implementasi Kurikulum. Jakarta: Kementerian Pendidikan dan Kebudayaan.

Kemendikbud. (2014). Program Pengembangan Kekhususan: Pedoman Pengembangan Orientasi Mobilitas, Sosial Dan Komunikasi untuk Peserta Didik Tunanetra.Jakarta: Kemendikbud.

Magalhaes, A.T., Sankako, A.N. \& Braccialli, L. MP. (2014). Strategies Used By Children's Education Teacher for Orientation and Mobility of the Visually Impaired Student. British Journal of Visual Impairment. 32, 157-169.

Majid, Abdul. (2012). Perencanaan Pembelajaran: Mengembangkan Standar Kompetensi Guru. Bandung: Remaja Rosdakarya.

Mumpuniarti. (2003). Ortopedagogik Tunagrahita. Yogyakarta: FIP UNY

Ratnasari \& Pamuji. (2013). Penerapan Model Pembelajaran Langsung untuk Meningkatkan Orientasi Mobilitas Anak Tunanetra di Pendidikan Khusus Negeri Seduri Mojosari. Jurnal Pendidikan khusus. 1-11

Riyana, Cepi. (2009). Komponen-komponen pembelajaran. Modul 6. Bandung UPI.
Rudiyati, S. (2002). Pendidikan Anak Tunanetra. Yogyakarta: FIP UNY.

Smith, D. D. \& Tyler, N.C. (2010).Introduction to Special Education. London: Pearson

Sudijono, Anas. (2007). Pengantar Evaluasi Pendidikan Edisi 7. Jakarta: Raja Grafindo Persada.

Sugiyono. (2012). Metode Penelitian Pendidikan: Pendekatan Kuantitatif, kualitatif dan $R \& D$. Bandung : Alfabeta

Turnbull, A., Turnbull, R., Wehmeyer, M. L., \& Shogren, K. A. (2013). Exceptional Lives: Special Education In Today's Schools.Seventh Edition. USA: Pearson..

Widjaya, A. (2013). Seluk Beluk Tunanetra dan Strategi Pembelajarannya. Yogyakarta: Javalutera 